Independent forecasts

July 2009

\title{
UK forecasts
}

The tables below supplement the Economic Review by providing a forward-looking view of the UK economy. The tables shows the average and range of independent forecasts for 2009 and 2010 and are extracted from HM Treasury's Forecasts for the UK Economy.

2009

\begin{tabular}{lrrr}
\hline & Average & Lowest & Highest \\
\hline GDP growth (per cent) & -4.0 & -4.4 & -3.1 \\
Inflation rate (Q4, per cent) & & & \\
CPI & 1.1 & -0.6 & 1.8 \\
RPI & -1.3 & -2.8 & 1.0 \\
Claimant count (Q4, million) & 1.99 & 1.60 & 2.60 \\
Current account (f billion) & -29.5 & -56.0 & -11.2 \\
Public Sector Net Borrowing & 180.8 & 155.0 & 202.0 \\
$\quad(2008-09, f$ billion) & & &
\end{tabular}

2010

\begin{tabular}{lrrr}
\hline & Average & Lowest & Highest \\
\hline GDP growth (per cent) & 0.7 & -1.3 & 2.0 \\
Inflation rate (Q4, per cent) & & & \\
CPI & 1.7 & 0.5 & 3.5 \\
RPI & 2.7 & 0.6 & 4.4 \\
Claimant count (Q4, million) & 2.29 & 1.57 & 3.10 \\
Current account (f billion) & -28.7 & -107.4 & -0.8 \\
Public Sector Net Borrowing & 184.2 & 154.0 & 240.0 \\
$\quad(2009-10, \mathrm{f}$ billion) & & & \\
\hline
\end{tabular}

\section{Notes}

Forecast for the UK economy gives more detailed forecasts, and is published monthly by HM Treasury. It is available on the Treasury's website at: www.hm-treasury.gov.uk/data_forecasts_index.htm

\section{Selected world forecasts}

The tables below supplement the Economic Review by providing a forward-looking view of the world economy. The tables show forecasts for a range of economic indicators taken from Economic Outlook (June 2009), published by OECD (Organisation for Economic Co-operation and Development).

2009

\begin{tabular}{lrrr}
\hline & US & Japan & Total OECD area \\
\hline Real GDP growth (per cent) & -2.8 & -6.8 & -4.8 \\
Consumer price (percentage change from previous year) & -0.6 & -1.4 & 0.5 \\
Unemployment rate (per cent of the labour force) & 9.3 & 5.2 & .4 .1 \\
Current account (as a percentage of GDP) &.. &.. \\
Fiscal balance ( as a percentage of GDP) & -10.2 & -7.8 &.. \\
\hline
\end{tabular}

2010

\begin{tabular}{|c|c|c|c|c|}
\hline & US & Japan & Euro area & Total OECD \\
\hline Real GDP growth (per cent) & 0.9 & 0.7 & 0.0 & 0.7 \\
\hline Consumer price (percentage change from previous year) & 1.0 & -1.4 & 0.7 & .. \\
\hline Unemployment rate (per cent of the labour force) & 10.1 & 5.7 & 12.0 & 9.8 \\
\hline Current account (as a percentage of GDP) & .. & .. &.. & .. \\
\hline Fiscal balance ( as a percentage of GDP) & -11.2 & -8.7 & -7.0 & -8.8 \\
\hline
\end{tabular}

\section{Notes}

The OECD Economic Outlook is published bi-annually. Further information about this publication can be found at www.oecd.org/eco/Economic_Outlook 